\title{
Expression of recombinant tilapia insulin-like growth factor-I and stimulation of juvenile tilapia growth by injection of recombinant IGFs polypeptides
}

\author{
Jyh-Yih Chen a,b, Jian-Chyi Chen ${ }^{\text {a }}$, Chi-Yao Chang a , \\ Shih-Chieh Shen ${ }^{\mathrm{b}}$, Meng-Shu Chen ${ }^{\mathrm{c}}$, Jen-Leih Wu ${ }^{\mathrm{a}, *}$ \\ ${ }^{a}$ Laboratory of Marine Molecular Biology and Biotechnology, Institute of Zoology, Academia Sinica, Taipei \\ 11529, Taiwan \\ ${ }^{\mathrm{b}}$ Institute of Zoology, National Taiwan University, Taipei, Taiwan \\ ${ }^{c}$ Department of Animal Science, National Taiwan University, Taipei, Taiwan
}

Accepted 24 June 1999

\begin{abstract}
Mature recombinant tilapia insulin-like growth factor-I (IGF-I) polypeptide was produced in Escherichia coli by cloning the IGF-I B to D domains with glutathione-S-transferase (GST, pGEX-2T vector). The recombinant IGF-I fusion protein, produced following induction of $E$. coli with IPTG induction and digestion with thrombin, appeared as a major protein band with a molecular mass of $7 \mathrm{kDa}$. Recombinant tilapia IGF-I ([GSPGIHM]-IGF-I) polypeptide bioactivity, as measured in a homologous $\left[{ }^{3} \mathrm{H}\right]$ thymidine incorporation assay assessing concentrations ranging from 0 to $120 \mathrm{nM}$, was found to significantly stimulate cell uptake of $\left[{ }^{3} \mathrm{H}\right]$ thymidine. The stimulatory effect of recombinant tilapia IGF-I polypeptide is suggested to be dose dependent. Recombinant tilapia IGF-I and IGF-II polypeptides at doses of $0.1,0.5,1$ and $2 \mu \mathrm{g}$ (g body weight per fish) ${ }^{-1}$ were injected into juvenile tilapia once a week. At doses of $2 \mu \mathrm{g}$ IGF-I (g body weight per fish) ${ }^{-1}$ and doses of $2 \mu \mathrm{g}$ IGF-II (g body weight per fish) ${ }^{-1}$, there were significant increases $(* * P<0.01)$ from week 5 onwards in both body weight $(73 \%$ for IGF-I, $72 \%$ for IGF-II), weight gain (270\% for IGF-I, $260 \%$ for IGF-II), and body length (33\% for IGF-I,
\end{abstract}

\footnotetext{
* Corresponding author. Tel.: + 886-2-27899534; fax: + 886-2-27824595
} 
$34 \%$ for IGF-II) relative to a similarly treated GST protein control group and untreated group. (C) 2000 Elsevier Science B.V. All rights reserved.

Keywords: Oreochromis mossambicus; Insulin-like growth factor; Protein expression; Growth promotion

\section{Introduction}

Mature insulin-like growth factor-I (IGF-I) is a single chain polypeptide with 70 amino acid residues. It plays a central role in regulating somatic growth in all vertebrates via the modulation of growth hormone (GH) (Mathews et al., 1986). The IGF-I prepropeptide consists of S, B, C, A, D and E domains; the S and E domains being cleaved from the other domains during post-translational processing of the propeptide, prior to the secretion of the mature IGF-I into serum. In vertebrates, the effects of IGF-I on somatic growth and cell differentiation are regulated by GH and nutritional conditions (Clemmons and Underwood, 1991; Conover et al., 1993). GH increases the abundance of IGF-I mRNA by enhancing the transcription of the IGF-I gene, as well as affecting the processing of IGF-I mRNA (Daughaday and Rotwein, 1989).

In order to study the role of IGF in aquaculture applications, it is necessary to obtain significant amounts of IGF. Up to now, many fish recombinant IGF polypeptides have been expressed in Escherichia coli, including those of salmon, trout and hagfish (Moriyama et al., 1993; Gentil et al., 1996; Upton et al., 1997). Many experiments have used non-piscine proteins and antibodies which may present variable growth-mediating effects in fish physiological studies. When using recombinant bovine IGF-I to study osmoregulation, it was discovered that rbIGF-I directly stimulates gill $\mathrm{Na}(+), \mathrm{K}(+)$ ATPase (Madsen and Bern, 1993). High doses of recombinant bovine IGF-I resulted in hypoglycemia and death; while other results indicate that exogenous treatment with mammalian IGF-I can stimulate coho salmon growth (McCormick et al., 1992). In rainbow trout pituitary cells, it was found that recombinant human IGF-I inhibited basal GH release at both 6 and $20 \mathrm{~h}$ after IGF-I stimulation, and GH release was dose dependent between 0.01 and $100 \mathrm{mM}$ (Perez-Sanchez et al., 1992). Recombinant bovine IGF-I also improved the osmoregulatory ability of trout, the results suggesting that IGF-I is a potential mediator of the action of $\mathrm{GH}$ in seawater adaptation of salmonids (McCormick et al., 1991). These experiments have always used non-piscine IGF-I polypeptides to examine physiological phenomena in fish. However, it is understandable that non-piscine IGF-I polypeptides should produce highly active stimulation and mediation effects in several fish species (Chen et al., 1998).

For the long-term study of IGFs in fish physiology, obtaining fish IGF-I polypeptides for preparing monoclonal antibodies is highly desirable and will play a key role in physiological experiments. Therefore, we have constructed a mature IGF-I nucleotide sequence linked to a glutathione- $S$-transferase (GST) gene fusion system (pGEX-2T vector) for expression of tilapia IGF-I in $E$. coli. We report here a one-step purification scheme that is adequate for purification of the tilapia IGF-I recombinant polypeptide. In addition, a preliminary investigation of the effect of tilapia recombinant IGF polypeptides on fish growth is reported in this paper. Our major objective is to determine 
whether growth of tilapia can be enhanced by injection of tilapia recombinant IGF peptides. Upon injection of IGF-I, IGF-II (Chen et al., 1997) purified peptides, and crude GST protein into juvenile tilapia, we found that IGF-I and IGF-II recombinant peptides have growth-promoting activities that suggest a potential usefulness in aquaculture.

\section{Materials and methods}

\subsection{Oligonucleotides}

In order to amplify the mature IGF-I peptide, the PCR primers, IGF-I B and D domains, were used. The IGF-I S to E domains DNA fragment was used as a template. The cloning methods of IGF-I S to E domains DNA fragment are described in detail by Chen et al. (1998). The PCR cloning primers were designed for obtaining the mature tilapia IGF-I nucleotide sequence based on known tilapia IGF-I B and D domains (B domain primer: 5'-CGGAATTCATATGGGCCCTGAGACCCTGTGCGGG; D domain primer: 5'-CGGAATTCCTCAAGAAATCTTGGGAGTCTTGAC) (Chen et al., 1998). These two primers were designed to also contain an EcoRI site. In addition, an ATG start codon was added in front of the tilapia IGF-I coding sequence, and a stop codon was designed to be immediately after the final serine codon. All primers were synthesized by Quality Systems, Taiwan.

\subsection{Construction of recombinant tilapia IGF-I expression vector}

The GST gene fusion system (Pharmacia Biotech) was used, along with the E. coli host cell, BL21(DE3). The pGEX-2T expression plasmid contains a nucleotide of 12 amino acid sequence with a thrombin digestion sequence and three cloning sites (Chen et al., 1996). The 0.2-kb PCR products from IGF-I B to D domains were digested with $E c o$ RI restriction enzyme and then cloned into the pGEX-2T expression vector (Fig. 1). Moreover, this plasmid was transformed into BL21(DE3) E. coli cells, and positive colonies were selected by ampicillin resistance. In order to identify the correct orientation of the inserted IGF-I cDNA, all colonies were sequenced.

\subsection{Expression and semi-purification of tilapia IGF-I}

The GST gene fusion system uses a tac promoter for chemical inducibility and to obtain high levels of expression. Smith and Johnson (1988) produced a very detailed report about a one-step process for the purification of recombinant protein from $E$. coli using the GST gene fusion system. Hartman et al. (1992) also reported on the affinity purification of insoluble recombinant fusion proteins containing GST. These papers of Smith and Johnson (1988) and Hartman et al. (1992) were used as the basis for expression to purification of the tilapia IGFs recombinant polypeptides. A single colony of $E$. coli cells containing the pGEX2T-IGF-I plasmid was incubated in $100 \mathrm{ml}$ of $2 \times$ YTA medium (tryptone $16 \mathrm{~g} / \mathrm{l}$; yeast extract $10 \mathrm{~g} / \mathrm{l} ; \mathrm{NaCl} 5 \mathrm{~g} / \mathrm{l}$; ampicillin final 

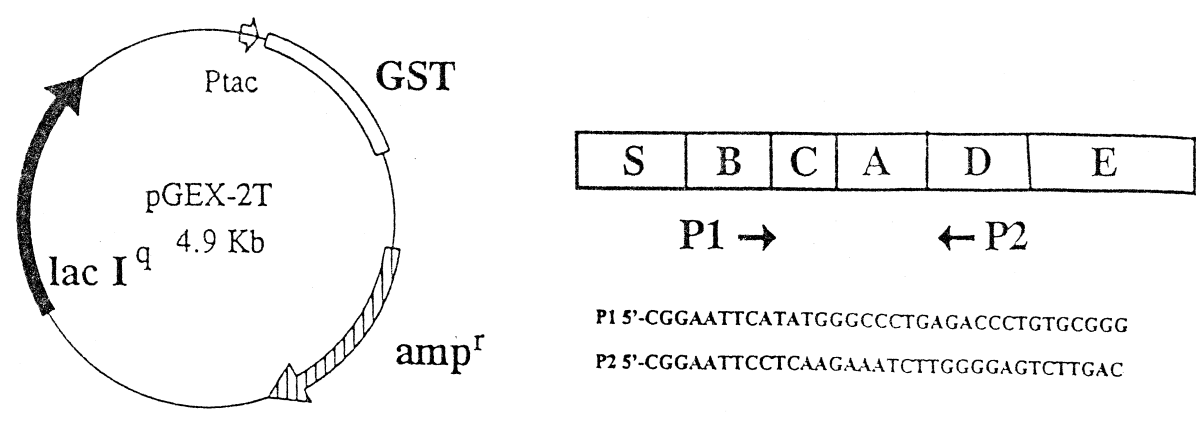

P1 5'-CGgaAtTCATATgGGCCCtGaGaccCtGTGCGGG

P2 5'-CGGAATTCCTCAAGAAATCTTGGGGAGTCTTGAC

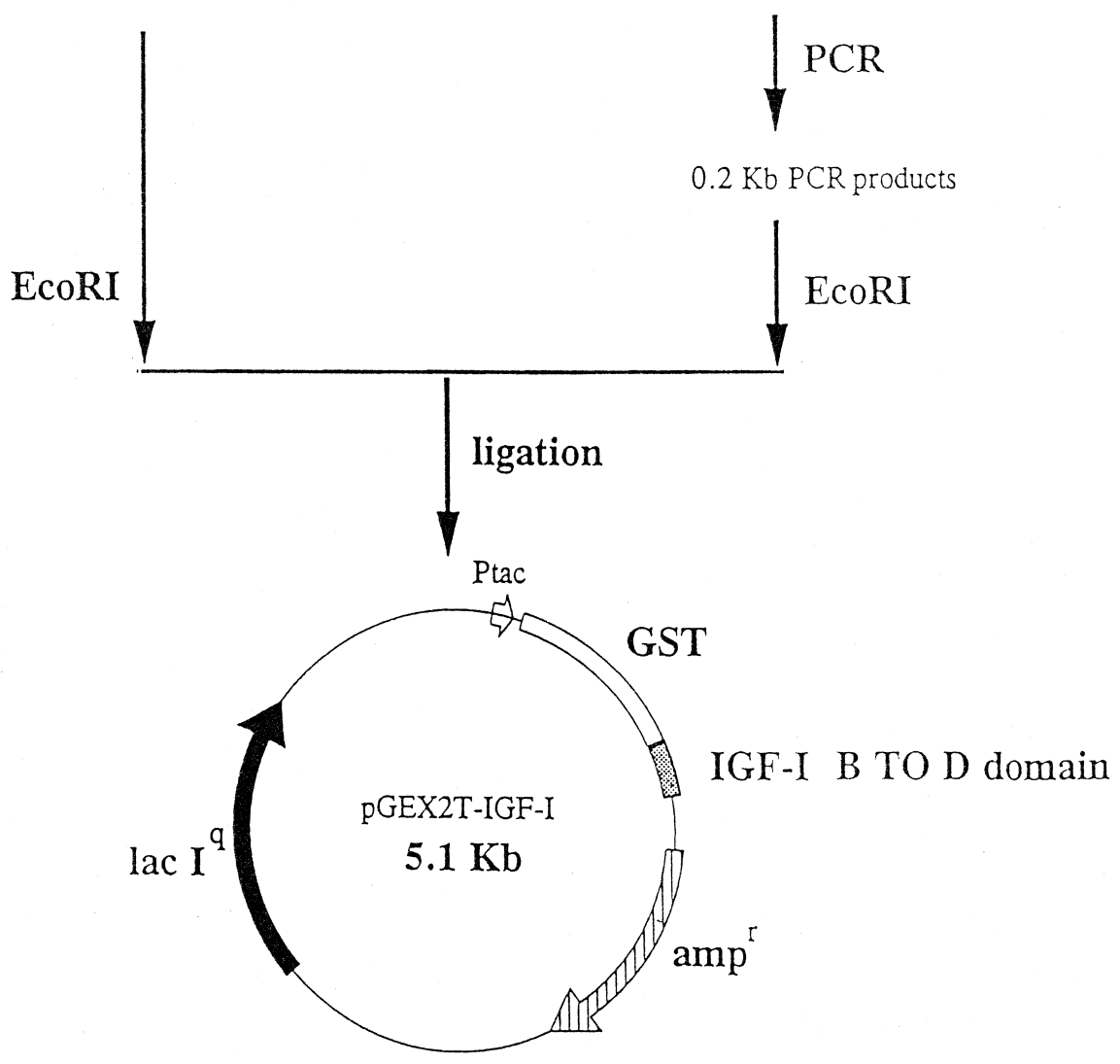

Fig. 1. Construction of the expression plasmid for tilapia IGF-I mature peptide (from B to D domains). Ptac indicates the tac promoter for inducible expression of GST. GST indicates glutathione $S$-transferase. There are multiple cloning sites after GST; the IGF-II B to D domains were ligated with the GST gene, and this produced a fusion protein. The IGF-I cDNA was originally constructed with pBluescript vector. Arrows indicate the orientation of the genes. Amp ${ }^{\mathrm{r}}$ : gene coding for ampicillin resistance; lac $^{\mathrm{q}}$ : the gene product was a lac repressor. 
concentration of $100 \mu \mathrm{g} / \mathrm{ml}$ ) with vigorous shaking for $10 \mathrm{~h}$ at $37^{\circ} \mathrm{C}$. The culture was then transferred to $500 \mathrm{ml}$ of 2 YTA medium and grown at $37^{\circ} \mathrm{C}$ with shaking until the absorbance at $600 \mathrm{~nm}$ was 1.1 . IPTG was added to a final concentration of $0.1 \mathrm{mM}$ and the culture was shaken at $22^{\circ} \mathrm{C}$ for $3 \mathrm{~h}$. Cells were collected by centrifugation at $7700 \times g$ for $10 \mathrm{~min}$ at $4^{\circ} \mathrm{C}$ and resuspended in $50 \mu \mathrm{l}$ ice-cold $1 \times$ PBS $(10 \times$ PBS; 1.4 $\mathrm{M} \mathrm{NaCl}, 27 \mathrm{mM} \mathrm{KCl}, 101 \mathrm{mM} \mathrm{Na}{ }_{2} \mathrm{HPO}_{4}, 18 \mathrm{mM} \mathrm{KH}_{2} \mathrm{PO}_{4}$ [pH 7.3]) per milliliter of culture. The cells were disrupted by sonication, and Triton X-100 was added to a final concentration of $1 \%$. This was mixed gently for $30 \mathrm{~min}$. After centrifugation at $12,000 \times g$ for $10 \mathrm{~min}$ at $4^{\circ} \mathrm{C}$, the supernatant was passed through a $0.45-\mu \mathrm{m}$ filter and then passed through the RediPack Purification Module (Pharmacia Biotech). The column was washed with $1 \times$ PBS and a solution containing $100 \mu 1$ thrombin solution (500

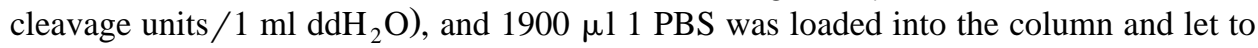
stand at 25 for $16 \mathrm{~h}$. The fraction of the reaction mixture containing IGF-I polypeptide ([GSPGIHM]-IGF-I) was eluted and collected, and cell protein was collected by resin. The recombinant proteins were run on an SDS-PAGE gel, then transferred to a PVDF membrane for amino acid sequencing to verify the fraction which contained the IGF-I recombinant polypeptide. An automated Edman degradation technique was used to determine the N-terminal amino acid sequence (ABI model 470a gas phase sequencer; Foster City, CA, USA). The protein purity was estimated by SDS-PAGE and the amount of protein present determined using spectrophotometric methods.

\subsection{Bioassay}

Tilapia ovary cells $\left(3 \times 10^{4}\right.$ cells well $\left.^{-1}\right)$ were seeded in 24 -well plates with MEM/F12 media supplemented with $10 \%$ serum. The cells were then washed and incubated in phenol red-free DMEM supplemented with $0.1 \%$ BSA for $24 \mathrm{~h}$. After $24 \mathrm{~h}$ serum-free incubation, the cells were incubated with or without various concentrations of IGF-I (0-120 nM) for $18 \mathrm{~h}$. The cells were then pulse labelled with $\left[{ }^{3} \mathrm{H}\right]$ thymidine (2 $\mu \mathrm{Ci} \mathrm{ml}{ }^{-1}$ ) for $2 \mathrm{~h}$ at $25^{\circ} \mathrm{C}$. The media was removed, $0.5 \mathrm{ml}$ of $0.3 \mathrm{~N} \mathrm{NaOH}$ was added, and after $5 \mathrm{~min}$ transferred to scintillation vials. Next, $5 \mathrm{ml}$ Aquasol was added and the solution was counted in a scintillation counter. Three replicates of each parameter were run. Every analysis in this experiment was repeated 3 times. $\left[{ }^{3} \mathrm{H}\right]$ Thymidine was incorporated into DNA in the Tilapia Ovary Cell Line (TO-2) (Chen et al., 1983; Chen et al., 1997).

\subsection{Growth promoting activity bioassay}

A total of 600 tilapia with an average of $1.30 \pm 0.31 \mathrm{~g}$ body weight and $4.51 \pm 0.38$ $\mathrm{cm}$ total length were randomly divided into 30 groups. Three separate indoor tanks $(45 \times 30 \times 30 \mathrm{~cm})$ held fish from a single condition group with each tank containing 20 tilapia. Room temperature was $25 \pm 1^{\circ} \mathrm{C}$ and a 12-h light:12-h dark cycle was maintained (lights on at $0900 \mathrm{~h}$ ). Fish were maintained in freshwater and fed once daily with meal particle (crude protein, 32\%; crude lipid, 5\%; fiber, 2\%; moisture, 9\%; Amazon Feed Taiwan) at a ratio of $5 \%$ of total wet weight throughout the experiments. Nine groups of tilapia were Chen et al., 1997), and crude GST protein (from expression of $E$. 
coli containing only the pGEX-2T vector), respectively, once a week. One other group received no treatment. The experiment dosage conditions were divided into $0.1,0.5,1$, and $2 \mu \mathrm{g}$ (g body weight per fish) ${ }^{-1}$ for IGF-I (IGF-I 0.1, IGF-I 0.5, IGF-I 1, IGF-I 2) and IGF-II groups (IGF-II 0.1, IGF-II 0.5, IGF-II 1, IGF-II 2), and $2 \mu \mathrm{g}$ (g body weight per fish) ${ }^{-1}$ for GST. The wet body weight and total length of fish were measured once every 2 weeks. Body weight gain $(\%)$ was calculated as $(\mathrm{WT}-\mathrm{wt}) \times \mathrm{wt}^{-1} \times 100$, where wt and WT represent initial and final mean wet weight; body length gain (\%) was calculated with a similar equation. (Body length gain was measured as the body length distance from the tip of the lower jaw to the fork [cm].) All data were analyzed by one-way analysis of variance. Duncan's multiple range test was used to determine pairs of groups that differed significantly at the 0.01 level.

\section{Results}

3.1. Expression, semi-purification and sequencing of tilapia IGF-I recombinant polypeptide

DNA encoding the mature tilapia IGF-I peptide was ligated with pGEX-2T expression vector and used to transform E. coli BL21(DE3). Expression of the IGF-I encoded

\section{$\begin{array}{lllllll}1 & 2 & 3 & 4 & 5 & 6 & 7\end{array}$}

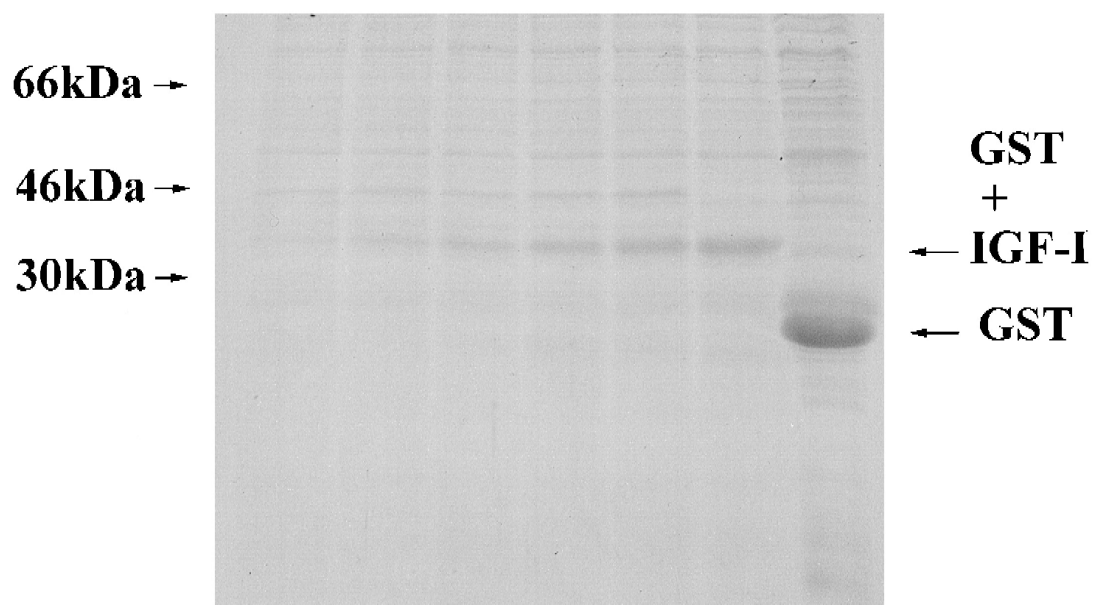

Fig. 2. Expression of tilapia IGF-I mature peptide in E. coli BL21(DE3). Cells were cultured in 2 YT medium with $100 \mu \mathrm{g} / \mathrm{ml}$ ampicillin at $37^{\circ} \mathrm{C}$ until the $\mathrm{OD}_{600}$ reached $0.4-0.6$. Then, the temperature was shifted to $22^{\circ} \mathrm{C}$, and $0.1 \mathrm{mM}$ IPTG was added for induction of tilapia IGF-I mature peptide synthesis. The cells were harvested after 30, 60, 90, 120, 150 and 180 min induction, and total proteins were analyzed by SDS-PAGE on $10 \%$ gel with Coomassie blue staining. Lane 1: The protein expressed contains pGEX-2T vector alone (GST protein). Lane 2: Cells containing the IGF-I insert after induction for $180 \mathrm{~min}$. Lane 3: Cells containing the IGF-I insert after induction for $150 \mathrm{~min}$. Lane 4: Cells containing the IGF-I insert after induction for $120 \mathrm{~min}$. Lane 5: Cells containing the IGF-I insert after induction for $90 \mathrm{~min}$. Lane 6: Cells containing the IGF-I insert after induction for $60 \mathrm{~min}$. Lane 7: Cells containing the IGF-I insert after induction for $30 \mathrm{~min}$. 
in the vector was induced with IPTG. Fig. 2 indicates the amount of recombinant protein expressed from 30 to $120 \mathrm{~min}$ after IPTG induction. In Fig. 3, lane 1 shows the expression protein with the pGEX-2T vector alone, lane 2 shows the expression protein with the pGEX-2T-ligated IGF-I insert, while lane 3 shows the expression protein after thrombin digestion and appearing as a single band. A 4-1 fermentation of E. coli BL21(DE3) cells transformed with tilapia pGEX2T-IGF-I expression vector yielded 2 mg of IGF-I recombinant polypeptide after column purification. The protein was also run with SDS-PAGE gel and then transferred to a PVDF membrane, after which a 7-kDa band was excised to perform and identify the amino acid sequencing (Table 1).

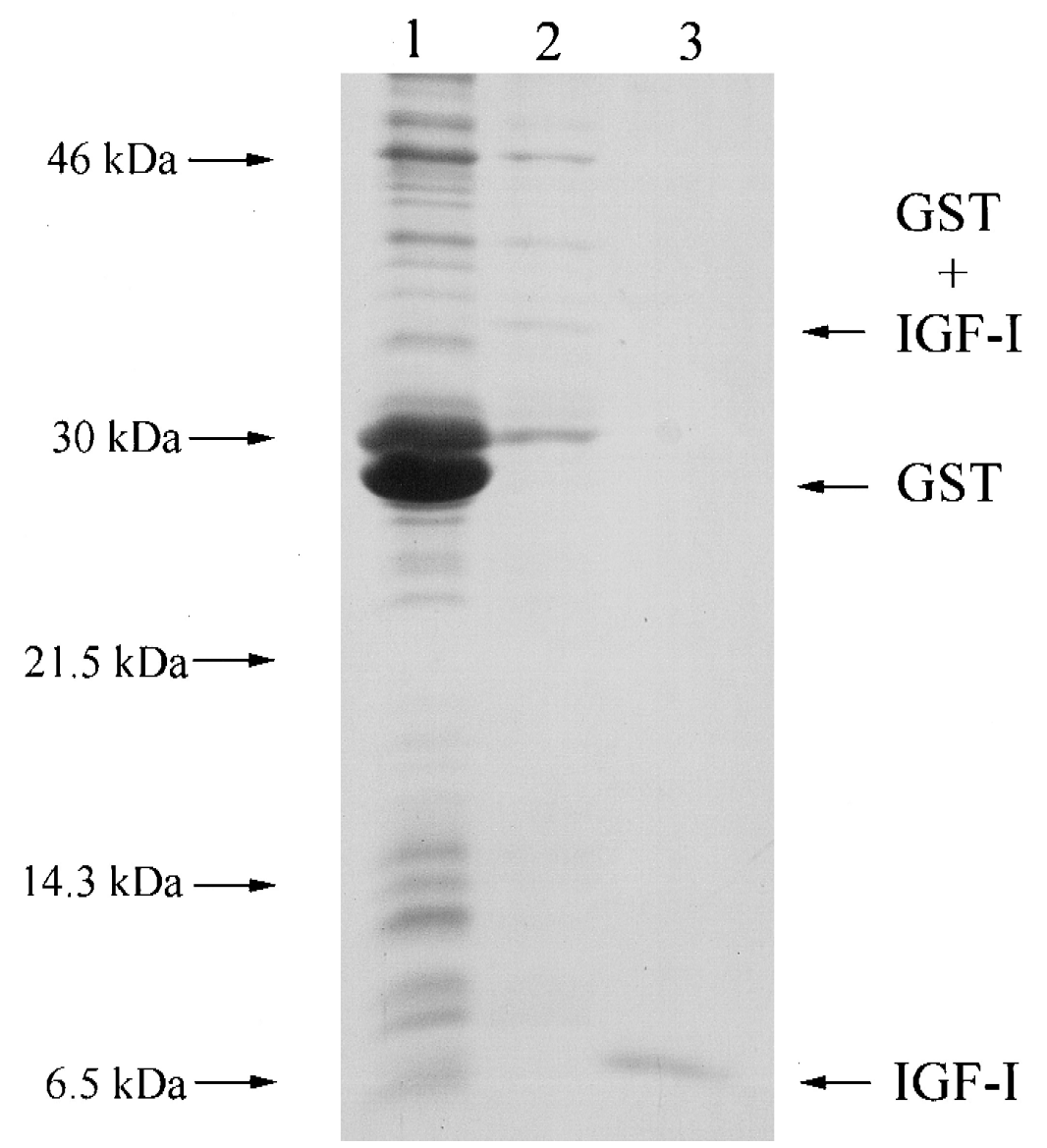

Fig. 3. Expression of tilapia IGF-I mature peptide in E. coli BL21(DE3). The E. coli cell culture conditions were the same as in Fig. 2. When the cell cultures were harvested after 180 min induction, the fusion proteins were digested with thrombin and purified by RedPack Module (Pharmacia Biotech). In Fig. 3, lane 1 shows the expression protein with the pGEX-2T vector alone, lane 2 shows the expression protein with the pGEX-2T-ligated IGF-I insert, while lane 3 shows the expression protein after thrombin digestion and appearing as a single band. The proteins were analyzed by SDS-PAGE on $15 \%$ gel, then the gel was transferred to a PVDF membrane and a single band was excised to do amino acids sequencing and to identify that the polypeptide is tilapia IGF-I. 


\section{Table 1}

Differences in amino acid sequences between the predicted and actual expression of recombinant polypeptides. Dots indicate predicted expression of amino acids identical to the actual expression of amino acids from amino acid sequences data. Dashes indicate amino acids after Edman protein sequencing referring to cycles where no PTH-amino acid derivative was detected; Cys residues could not be judged here

\begin{tabular}{ll}
\hline & Amino acid sequence \\
\hline Predicted expression amino acid & GPETLCGAELVDT ... \\
Actual expression amino acid & GSPGIHMGPETL-GAELVDT $\ldots$ \\
\hline
\end{tabular}

\subsection{Characterization of recombinant tilapia IGF-I polypeptide}

The tilapia ovary cell line was employed to test the bioactivity of recombinant tilapia IGF-I polypeptide. The incorporation of $\left[{ }^{3} \mathrm{H}\right]$ thymidine at polypeptide concentrations in the range of $0-120 \mathrm{nM}$ was shown to be significant (ANOVA; $F=4.46 ; d f=6,14$; $\left.{ }^{*} P<0.05\right)$ and concentration dependent. The data are shown in Fig. 4. The data suggests that TO-2 cell membranes may have IGF-I receptors that mediate the dose-dependent effect observed.

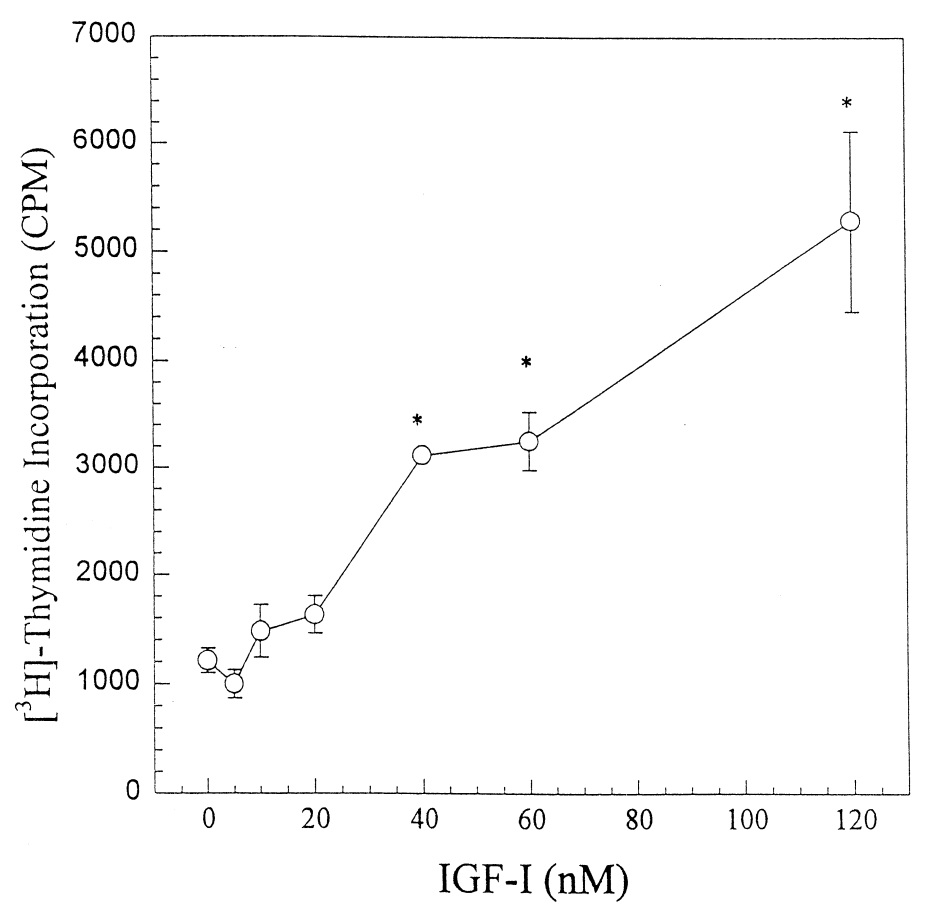

Fig. 4. Effects of recombinant tilapia IGF-I polypeptide on stimulated tilapia ovary cell (TO-2 cell line) proliferation. The following effects were measured for different concentrations of recombinant tilapia IGF-I. Increased exposure periods resulted in increased incorporation of $\left[{ }^{3} \mathrm{H}\right]$ thymidine into DNA synthesis. Asterisks indicate that the value is significantly different $\left({ }^{*} P<0.05\right)$ from the other groups. The $\left[{ }^{3} \mathrm{H}\right]$-thymidine into DNA synthesis experiment was repeated three times. 


\subsection{Effects of tilapia recombinant IGFs polypeptides on fish growth}

To identify whether tilapia recombinant IGF-I and IGF-II produced in E. coli system are biologically active, we injected juvenile tilapia with the semi-purified peptides obtained from the one-step purification. This administration led to significant growth

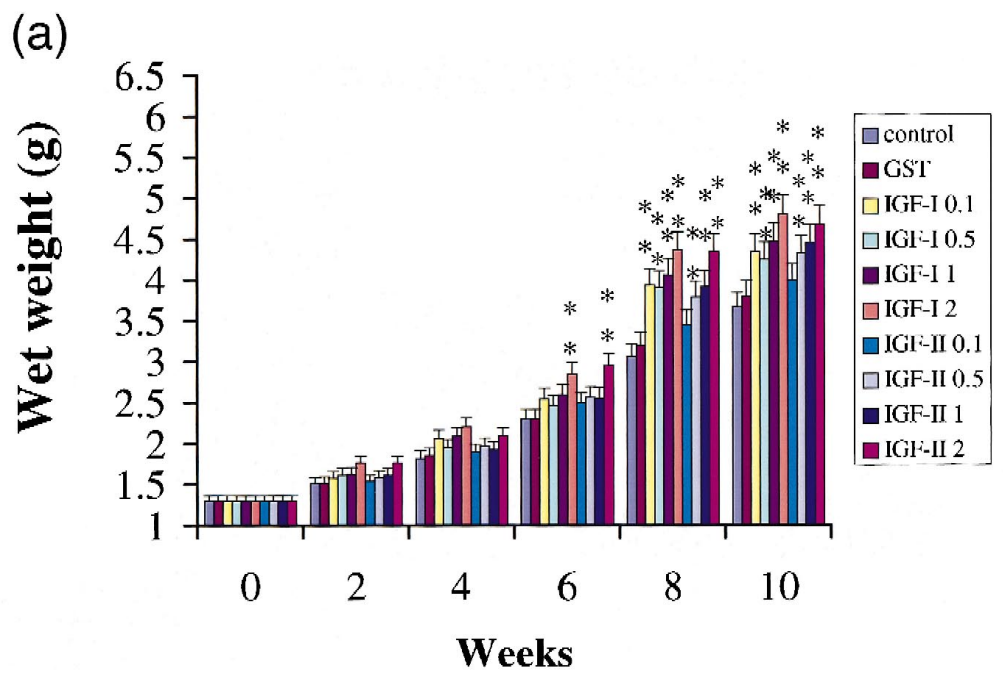

(b)

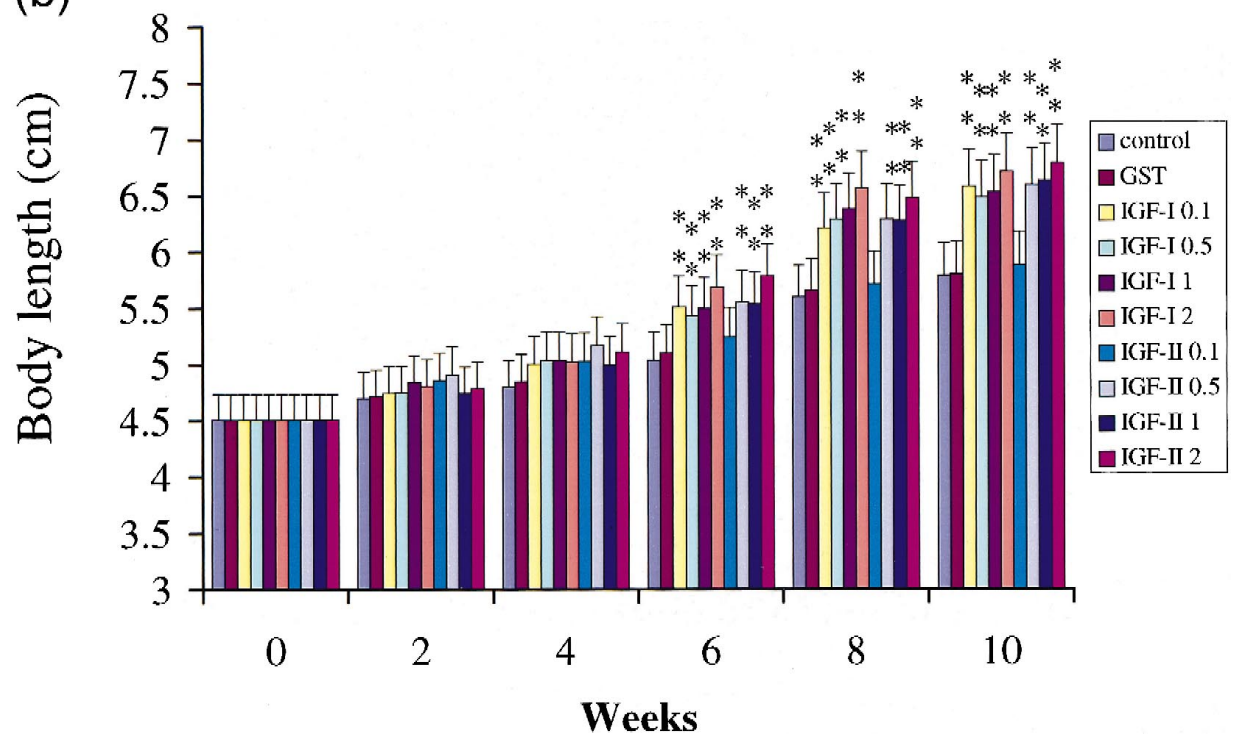

Fig. 5. Effect of injection of recombinant IGF-I and IGF-II on juvenile tilapia over a 10-week period. The body wet weight (a) and body length (b) are shown here. IGF-I and IGF-II at concentrations of 2, 1, 0.5 and $0.1 \mu \mathrm{g}$ were injected intraperitoneally once a week; different colors indicate the different polypeptides shown in the picture. Wet body weights and total body lengths are shown as means $\pm \operatorname{SD}(n=60)$. 
enhancement that was evident after 10 weeks of treatment (Fig. 5). The recombinant IGF-I and IGF-II polypeptides promoted growth in this experiment at the concentrations tested $\left(0.1,0.5,1\right.$ and $2 \mu \mathrm{g}$ (g body weight per fish) $\left.{ }^{-1}\right)$. The results indicate that higher doses led to greater growth rates except for IGF-II 0.1 (injected $0.1 \mu \mathrm{g}$ (g body weight per fish) ${ }^{-1}$ ). After 10 weeks, fish injected with IGF-I and IGF-II showed a statistically significant difference $(* * P<0.01)$ in body weight gain in comparison with the GST group and untreated group. However, an IGF-II dose of $0.1 \mu \mathrm{g}$ (g body weight per fish $)^{-1}$ was not sufficient to promote an increase in weight. Similarly, an IGF-II dosage of $0.1 \mu \mathrm{g}$ (g body weight per fish $)^{-1}$ did not produce a conspicuous body length gain. At the end of the experiment, the effect of the treatments on body weight gain (\%) were: IGF-I $2(269 \%)>$ IGF-II $2(259 \%)>$ IGF-I $1(244 \%)>$ IGF-II $1(242 \%)>$ IGF-I 0.1 $(234 \%)>$ IGF-II $0.5(231 \%)>$ IGF-I $0.5(226 \%)>$ IGF-II $0.1(200 \%)>$ GST $(161 \%)$ $>$ untreated $(153 \%)$. The highest dose of recombinant tilapia IGF-I and IGF-II peptides used, IGF-II (or IGF-I) at $2 \mu \mathrm{g}$ (g body weight per fish) ${ }^{-1}$, proved to be more effective than the lowest dose of tilapia recombinant IGF-II (or IGF-I), at 0.1 or $0.5 \mu \mathrm{g}$ (g body weight per fish $)^{-1}$ in body weight gain. Comparison of the lowest dose of tilapia recombinant IGFs peptide shows that, between the lowest dosage of injected IGF peptides, IGF-I at $0.1 \mu \mathrm{g}$ (g body weight per fish) ${ }^{-1}$ was more effective than IGF-II at $0.1 \mu \mathrm{g}$ (g body weight per fish) ${ }^{-1}$ (Fig. 5). In general, the injection of recombinant IGF peptides was more effective at promoting an elevated body weight gain $(\%)$ in comparison with the GST control and untreated group $(* * P<0.01)$. After week 10 , the means of wet weight and total length for IGF-I $0.1,0.5,1$ and $2 \mu \mathrm{g}$ dosage groups increased to $4.34 \pm 1.66 \mathrm{~g}$ and $6.58 \pm 0.74 \mathrm{~cm}, 4.25 \pm 1.40 \mathrm{~g}$ and $6.48 \pm 0.64 \mathrm{~cm}$, $4.47 \pm 1.83 \mathrm{~g}$ and $6.53 \pm 0.82 \mathrm{~cm}$, and $4.80 \pm 1.32 \mathrm{~g}$ and $6.71 \pm 0.55 \mathrm{~cm}$, respectively; while those for IGF-II increased to $3.90 \pm 0.81 \mathrm{~g}$ and $588 \pm 0.47 \mathrm{~cm}, 4.33 \pm 1.30 \mathrm{~g}$ and $6.59 \pm 0.66 \mathrm{~cm}, 4.45 \pm 1.85 \mathrm{~g}$ and $6.63 \pm 0.76 \mathrm{~cm}$, and $4.67 \pm 1.50 \mathrm{~g}$ and $6.78 \pm 0.73$ $\mathrm{cm}$, respectively. On the other hand, the GST group and untreated group had means of wet weights and total lengths of $3.30 \pm 0.59 \mathrm{~g}$ and $5.79 \pm 0.38 \mathrm{~cm}$, and $3.41 \pm 0.72 \mathrm{~g}$ and $5.81 \pm 0.41 \mathrm{~cm}$, respectively.

\section{Discussion}

As in the case with proinsulin, the human native IGF-I molecule contains three disulfide bonds linking six cysteine residues. On the basis of mass spectrometric and enzymatic degradation studies, they are located at CysB6-CysA7, CysA6-CysA11 and CysB18-CysA20 (Iwai et al., 1989); in tilapia the linking disulfide bonds are also located at the same sites. The locations of the six cysteine residues in mature tilapia IGF-I are also found in tilapia IGF-II (Chen et al., 1997). These linkages are analogous to those chemically determined for insulin (Ryle et al., 1955).

Using competitive ligand binding studies, ligand blotting and immunoprecipitation, it was found that porcine follicular IGFBPs may play an important role in the IGF autocrine/paracrine regulatory system of the ovary (Adashi et al., 1990). IGF-I stimulates thymidine incorporation in immature and mature granulosa. There is much evidence that IGF-I, binding proteins, and receptors participate in mammalian ovarian 
follicular development and function (Zhou and Bondy, 1993). Thus, we tested the recombinant tilapia IGF-I polypeptide biological activity in vitro, in the Tilapia Ovary Cell Line, TO-2, to determine the thymidine incorporation rate. The results show a notable dose-dependent effect in tilapia ovary cell line (Fig. 4). Thus, it is reasonable to presume that the recombinant tilapia IGF-I mature peptide produced by the E. coli strain can be used for large-scale preparation of functional polypeptides, although the polypeptide with an N-terminal extension contains the amino acids GSPGIHM. This in turn is an important development for the study of tilapia physiology with applications for both basic research and aquaculture.

The results show a notable dose-dependent effect of the recombinant protein in the tilapia ovary cell line and conform to previous reports. In fish, the GH-IGF-I axis appears to be very important for fish growth (Gray and Kelley, 1991). Eel branchial cartilage can be stimulated to uptake sulfate by IGF-I (Duan and Hirano, 1992). In the in vivo growth promotion experiment reported here, the most effective dose of recombinant tilapia IGFs polypeptide for the enhancement of the growth rate of tilapia was $2 \mu \mathrm{g}$ (g body weight per fish) ${ }^{-1}$ of IGF-I and IGF-II. This dosage is much higher than those used for injecting E. coli-produced $\mathrm{GH}$ into rainbow trout at dosages of 0.2 and 1 $\mu \mathrm{g} /(\mathrm{g} \text { of fish body weight })^{-1}$ (Agellon et al., 1988).

In the present study, significant gains in both weight and length were achieved by IGF-treated fish after 4 weeks. These data from body weight gain suggest that injected recombinant IGF-I polypeptide was more effective than injected recombinant IGF-II for inducing body weight gain, and that IGF-II at $0.1 \mu \mathrm{g}$ (g body weight per fish) ${ }^{-1}$ was not helpful for growth promotion. Injecting rat with IGF-II (100 ng peptide animal ${ }^{-1}$ ) resulted in a $21 \%$ decrease in food intake and $4 \%$ body weight loss over a 24 -h period (Lauterio et al., 1987). Well-fed sheep administered IGF-I over an 8-week period showed virtually no growth-promoting effects (Cottam et al., 1992). However, infusion of IGF-I for 7 days had growth-promoting effects in energy-restricted normal rats, but not in ad libitum-fed rats (Schalch et al., 1989). The lack of a growth-promoting effect of IGF-I and IGF-II in these reports may be due to the use of low dosages and different animals. In hypophysectomized rats administered a 6-day subcutaneous infusion of IGF-I and IGF-II, it was found that IGF-I, but not IGF-II, led to an increase in body weight; and while both IGF-I and IGF-II stimulated widening of the costal cartilage, IGF-II was clearly less potent than was IGF-I (Schoenle et al., 1982). IGF-I stimulates growth in hypophysectomized rats (Schoenle et al., 1982). A few investigators have reported a growth-promotion effect in young rats administered IGF-I (Hizuka et al., 1986), as well as stimulation of coho salmon growth by IGF-I (McCormick et al., 1992). In normal chicks, rhIGF-I infusion had no effect on growth and little effect on plasma hormone levels except for a decrease in plasma insulin. In dwarf chicks, rhIGF-I infusion slightly increased body weight but had no effect on longitudinal bone growth. These results suggest that IGF-I in the chicken has no direct endocrine effect on statural growth (Tixier-Boichard et al., 1992). Results of daily injection of rhIGF-I in broiler chicken show that exogenous IGF-I did not affect the average daily gain, average daily feed consumption, or the gain-to-feed ratio (McGuinness and Coqburn, 1991).

These controversial results between IGF-I and IGF-II being different from ours may be due to differences in the species, development stages, and/or food consumption 
rates. The age of the fish might have played a role in the efficiency of recombinant IGF-I and IGF-II at improving growth. With mouse IGF-II, mRNA is strongly expressed throughout fetal growth and regulates body growth. In the bony fish barramundi (Lates calcarifer), the presence of IGF receptors was investigated in the liver by competitive binding studies. The results suggested the presence of a type 1-like but no type 2-like IGF receptor (Drakenberg et al., 1997). The IGF receptor was divided into two kinds of receptor. A binding site which preferred IGF-I over IGF-II and weakly recognized insulin was known as the type I receptor. A second binding site which preferred IGF-II over IGF-I and which did not recognize insulin was called the type II receptor. The type II receptor contributes to the degradation of extracellular IGF-II and receptor-mediated internalization. But its biological function is unclear (Nissley and Lopaczynski, 1991). Perhaps, it is reasonable to suggest that only a type I-like receptor, i.e., binding to IGF-I and IGF-II only, is present in teleost, with these type I receptors being involved in signal transduction of mitogenic stimuli, since following an increase in the injected dosage, the IGF-I and IGF-II treatment groups showed significant increases in body weight and body length. In our results (Fig. 5), we observed that in the IGF-I and IGF-II treatment groups, body weight increased at a greater rate than did body length. The anabolic effects of IGF-I and IGF-II may have useful potential for application to aquaculture. In particular, stimulation of protein synthesis in fish muscle by exogenous recombinant IGF-I or IGF-II, combined with feeding, may be a new method for aquaculture biotechnology. In summary, in the present investigation, we expressed the recombinant IGF-I polypeptide in $E$. coli, tested the bioactivity on the in vitro bioassay, injected IGFs into juvenile tilapia, and demonstrated that fish growth can be enhanced not only with $\mathrm{GH}$, but also with insulin-like growth factor.

\section{Acknowledgements}

We thank Dr. Ching-Ming Kuo and Dr. Cho-Fat Hui for valuable advice and scientific discussions. We thank Dr. I-Chiu Liao for his support and encouragement. This research was supported by grants from the National Science Council NSC83-0211B-001-037 (R.O.C.), NSC84-2321-B-001-014 (R.O.C.), and NSC87-2311-B-001-031B24 (R.O.C.) to Dr. Jen-Leih Wu.

\section{References}

Adashi, E.Y., Resnick, C.E., Rosenfeld, R.D., 1990. IGF-I and IGF-II hormonal action in cultured granulosa cells: mediation by I but not II receptors. Endocrinology 126, 216-221.

Agellon, L.B., Emery, C.J., Jones, J.M., Davies, S.L., Dingle, A.D., Chen, T.T., 1988. Promotion of rapid growth of rainbow trout (Salmo gairdneri) by a recombinant fish growth hormone. Can. J. Fish. Aquat. Sci. $45,146-151$.

Chen, S.N., Shi, S.C., Ueno, Y., Kou, G.H., 1983. A cell line derived from Tilapia ovary. Fish Pathol. 18, $13-18$.

Chen, Y.R., Yu, C.A., Yu, L., 1996. Functional expression of subunit IV of Rhodobacter sphaeroides cytochrome b-cl complex and reconstitution of recombinant protein with three-subunit core complex. J. Biol. Chem. 271 (4), 2057-2062. 
Chen, J.Y., Chang, C.Y., Chen, J.C., Shen, S.C., Wu, J.L., 1997. Production of biologically active recombinant tilapia insulin-like growth factor-II polypeptides in E. coli cells and characterization of the genomic structure of the coding region. DNA Cell Biol. 16, 883-892.

Chen, J.Y., Tsai, H.L., Chang, C.Y., Wang, J.I., Shen, S.C., Wu, J.L., 1998. Isolation and characterization of tilapia (Oreochromis mossambicus) insulin-like growth factors gene and proximal promoter region. DNA Cell Biol. 17, 359-376.

Clemmons, D.R., Underwood, L.E., 1991. Nutritional regulation of IGF-I and IGF binding protein. Annu. Rev. Nutr. 11, 383-412.

Conover, C.A., Baker, B.K., Bale, L.K., Clarkson, J.T., Liu, F., Hintz, R.L., 1993. Human hepatoma cells synthesize and secrete insulin-like growth factor Ia prohormone under growth hormone control. Regul. Pept. 48, 1-8.

Cottam, Y.H., Blair, H.T., Gallaher, B.W., Purchas, R.W., Breier, B.H., McCutcheon, S.N., Gluckman, P.D., 1992. Body growth, carcass composition, and endocrine changes in lambs chronically treated with recombinantly derived insulin-like growth factor-I. Endocrinology 130, 2924-2930.

Daughaday, W.H., Rotwein, P., 1989. Insulin-like growth factor I and II: peptide, messenger ribonucleic acid and gene structure, serum, and tissue concentrations. Endocr. Rev. 10, 68-91.

Duan, C., Hirano, T., 1992. Effects of insulin-like growth factor-I and insulin on the in vitro uptake of sulphate by eel branchial cartilage: evidence for the presence of independent hepatic and pancreatic sulphation factors. J. Endocrinol. 133, 211-219.

Gentil, V., Martin, P., Smal, J., Le-Bail, P.Y., 1996. Production of recombinant insulin-like growth factor-II in the development of a radioimmunoassay in rainbow trout (Oncorhynchus mykiss). Gen. Comp. Endocrinol. 104, 156-167.

Drakenberg, K., Carey, G., Mather, P., Anderson, A., Sara, V.R., 1997. Characterization of an insulin-like growth factor (IGF) receptor and the insulin-like effects of IGF-I in the bony fish, Lates calcarifer. Regul. Pept. 69, 41-45.

Gray, E.S., Kelley, K.M., 1991. Growth regulation in the gobiid teleost, Gillichthys mirabilis: roles of growth hormone, hepatic growth hormone receptors and insulin-like growth factor-I. J. Endocrinol. 131, 57-66.

Hartman, J., Daram, P., Frizzell, R.A., Rado, T., Benos, D.J., Sorscher, E.J., 1992. Affinity purification of insoluble recombinant fusion proteins containing glutathione-S-transferase. Biotechnol. Bioeng. 39, 828832.

Hizuka, N., Takano, K., Schizume, K., Asakawa, K., Mtvakawa, M., Tanaka, I., Horikawa, R., 1986. Insulin-like growth factor I stimulates growth in normal growing rats. Eur. J. Pharmacol. 125, 143-146.

Iwai, M., Kobayashi, M., Tamura, K., Ishii, Y., Yamada, H., Niwa, M., 1989. Direct identification of disulfide bond linkages in human insulin-like growth factor I (IGF-I) by chemical synthesis. J. Biochem. (Tokyo) 106, 949-951.

Lauterio, T.J., Marson, L., Daughaday, W.H., Baile, C.A., 1987. Evidence for the role of insulin-like growth factor II (IGF-II) in the control of food intake. Physiol. Behav. 40, 755-758.

Madsen, S.S., Bern, H.A., 1993. In-vitro effects of insulin-like growth factor-I on gill $\mathrm{Na}(+), \mathrm{K}(+)$-ATPase in coho salmon, Oncorhynchus kisutch. J. Endocrinol. 138, 23-30.

Mathews, L.S., Norstedt, G., Palmiter, R.D., 1986. Regulation of insulin-like growth factor I gene expression by growth hormone. Proc. Natl. Acad. Sci. U.S.A. 83, 9343-9347.

McCormick, S.D., Sakamoto, T., Hasegawa, S., Hirano, T., 1991. Osmoregulatory actions of insulin-like growth factor-I in rainbow trout (Oncorhynchus mykiss). J. Endocrinol. 130, 87-92.

McCormick, S.D., Kelley, K.M., Young, G., Nishioka, R.S., Bern, H.A., 1992. Stimulation of coho salmon growth by insulin-like growth factor I. Gen. Comp. Endocrinol. 86, 398-406.

McGuinness, M.C., Coqburn, L.A., 1991. Response of young broiler chickens to chronic injection of recombinant-derived human insulin-like growth factor-I. Domest. Anim. Endocrinol. 8, 611-620.

Moriyama, S., Duguay, S.J., Conlon, J.M., Duan, C., Dickhoff, W.W., Plisetskaya, E.M., 1993. Recombinant coho salmon insulin-like growth factor 1:expression in Escherichia coli, purification and characterization. Eur. J. Biochem. 218, 205-211.

Nissley, P., Lopaczynski, W., 1991. Insulin-like growth factor receptors. Growth Factors 5, 29-43.

Perez-Sanchez, J., Weil, C., Le-Bail, P.Y., 1992. Effects of human insulin-like growth factor-I on release of growth hormone by rainbow trout (Oncorhynchus mykiss) pituitary cells. J. Exp. Zool. 262, 287-290.

Ryle, A.P., Sanger, F., Smith, L.F., Kital, R., 1955. The disulphide bonds of insulin. Biochem. J. 60, 541. 
Schalch, D.S., Yang, H., Ney, D.M., DiMarch, R.D., 1989. Infusion of human insulin-like growth factor I (IGF-I) into malnourished rats reduces hepatic IGF-I mRNA abundance. Biochem. Biophys. Res. Commun. 160, 795-800.

Schoenle, E., Zapf, J., Humbel, R.E., Foresch, E.R., 1982. Insulin-like growth factor 1 stimulates growth in hypophysectomized rats. Nature (London) 296, 252-253.

Smith, D.B., Johnson, K.S., 1988. Single-step purification of polypeptides expressed in Escherichia coli as fusions with glutathione $S$-transferase. Gene 67, 31-40.

Tixier-Boichard, M., Huybrechts, L.M., Decuypere, E., Kuhn, E.R., Monvoisin, J.L., Coquerelle, G., Charrier, J., Simon, J., 1992. Effects of insulin-like growth factor-I (IGF-I) infusion and dietary tri-iodothyronine (T3) supplementation on growth, body composition and plasma hormone levels in sex-linked dwarf mutant and normal chickens. J. Endocrinol. 133, 101-110.

Upton, Z., Francis, G.L., Chan, S.J., Steiner, D.F., Wallace, J.C., Ballard, F.J., 1997. Evolution of insulin-like growth factor (IGF) function: production and characterization of recombinant hagfish IGF. Gen. Comp. Endocrinol. 105, 79-90.

Zhou, I., Bondy, C., 1993. Anatomy of the human ovarian insulin-like growth factor system. Biol. Reprod. 48, 467-482. 